POLLACK PERIODICA

An International Journal for Engineering and Information Sciences

DOI: $10.1556 / 606.2017 .12 .2 .9$

Vol. 12, No. 2, pp. 103-116 (2017)

www.akademiai.com

\title{
FLASH FLOOD MITIGATION MODELING - CASE STUDY SMALL CARPATHIANS
}

\author{
${ }^{1}$ Adam JANÍK, ${ }^{2}$ Andrej ŠOLTÉSZ \\ Department of Hydraulic Engineering, Faculty of Civil Engineering, Slovak University of \\ Technology in Bratislava, Radlinského 11, 81005 Bratislava, Slovakia \\ e-mail: ${ }^{1}$ adam.janik@stuba.sk, ${ }^{2}$ andrej.soltesz@stuba.sk
}

Received 16 December 2016; accepted 27 March 2017

\begin{abstract}
Flash floods are becoming a phenomenon that troubles people more and more often in many Slovak under-mountain regions and society needs to deal with these extreme natural events. This article is showing an example of mathematical modeling of flood protection measures in Small Carpathians region. To secure flood protection, detention reservoirs have been proposed, because of their automatic function that is important due to rapid progress of flash floods. As a base for this project a previous work that attempted to reconstruct the flood has been used. HEC-RAS 4.1.0 software package was used for numerical modeling, which includes flood mitigation calculation. Six variants of proposed detention reservoirs were created and checked by a design flood wave that was created according to rainfall with recurrence period of 100 years. All of the proposed detention reservoirs have exact proportions needed to secure flood protection including height of the dam, length of the dam in crest, type and dimension of outlet and dimensions of emergency spillways. The modeling included flood wave passing during several situations - normal function of detention reservoirs, blocked outlet and dam break. This study should be considered as a base for future flood protection project. An extensive terrain survey has been performed in frame of this project.
\end{abstract}

Keywords: Detention reservoir, Flood wave, Mathematical modeling, Flood protection

\section{Introduction}

Flash floods, which are also called storms or sudden floods, are a specific type of flood caused by heavy storms with considerable intensity, a typical sign of which is an intensive increase in the water level in a river in a short time period (usually a couple of hours). These are mostly flash floods in small streams in the upper parts of river basins, 
and they commence with extreme storm rainfalls. The intensity and duration of a rainfall are not possible to exactly determine because they are dependent on many factors including the type and shape of a landscape and the soil water saturation; nonetheless, they are often linked to anthropogenic activities (inadequate operations on a landscape).

Due to the extremely short time period when a flood commences, it is very difficult to warn the inhabitants of a region, and it is often too late to carry out operative flood protection measures, like as mobile flood-protection barriers. Number of fatalities depends strongly on the arrival time of the flood and also on warning time and evacuation procedures [1], [2], [3]. That is the reason why it is necessary to prepare for these kinds of floods with appropriate flood-protection measures, which do not require any operations and work automatically. The detention reservoirs surely possess these features.

In history, the flood mitigation problem has been described by a simple question as: How large does a reservoir need to be to meet a given inflow demand, [4], [5]. It is common hydrologic knowledge that reservoirs reduce and attenuate inflow hydrograph peaks. Incoming water is stored up to a proposed maximum capacity and the available storage limits the magnitude, which high flows can be mitigated. Reservoirs built for the purpose of flood mitigation modify the downstream flood frequency [6]. Distributed storage analyses have often been applied to storm-water management of urbanization areas, termed source control [7]. The same concept can be applied to agriculturally developed areas, also producing more runoff than natural conditions [8], [9] discussed the use of current roadway and culvert infrastructure modified for flood storage. Each upstream structure mitigates the impacts of intense rainfall at the location where they occur. Distributed structures offer the ability to attenuate peak flows across a basin, significantly reducing costs as compared to a single reservoir [10], [11].

The scope of this study aims to propose flood protection in village Píla using detention reservoirs. To match this goal a computer model in HEC-RAS software has been created. In chosen locations several variants of proposal with different heights and combinations of detention reservoirs were created. The final variant successfully secured flood protection for the village in case of appearance of the design flood wave.

\section{Flood on the Gidra in the village Píla (2011)}

People usually start noticing the adequacy of flood protection measures when a flood appears. The village of Píla, which was affected by a destructive flood in the year 2011, was no exception. After this flood, many buildings, roads and pavements had to be repaired, but flood protection was still not built.

On 7th June 2011, storm clouds formed above Slovakia; the most intensive storm activity was in the afternoon in the region of the Small Carpathians (on its southeast hills, which are part of the Trnava and Pezinok districts). Fifty-one to $100 \mathrm{~mm}$ of rain fell in this area and, in the most exposed places, the amount exceeded $100 \mathrm{~mm}$. The most dangerous phenomenon was not the rainfall itself, but the long duration of the very intensive rain. As a result of this rainfall, catastrophic floods occurred, which affected many river basins in the mentioned region. The most critical situation was at the Gidra, 
Parná and Vištucký streams, where the water levels rose up to a much higher limit than a level equivalent to the third stage of flood activity in less than 2 hours. The first peak occurred on 7th June at 17:00 in Píla on the Gidra stream, where the water level rose to $2.26 \mathrm{~m}$. Immediately after reaching its peak, the water level started to decline rapidly. The water level of the Gidra had quickly achieved a level adequate to the first stage of flood activity, but the next wave of the rain caused a repeated increase in the water level. This was the reason for the second flood wave, but it had a smaller range. After the second peak, the water level on the Gidra stream started to decrease until it dropped below the value of the first stage of flood activity in the afternoon hours (Fig. 1). Later the peak discharge was determined to have a value of $Q_{c u l m}=44.5 \mathrm{~m}^{3} . \mathrm{s}^{-1}$, which was according to the T-years discharges, provided by hydrological institute, representing return period of more than a 1000-year discharge [12], [13], [14].

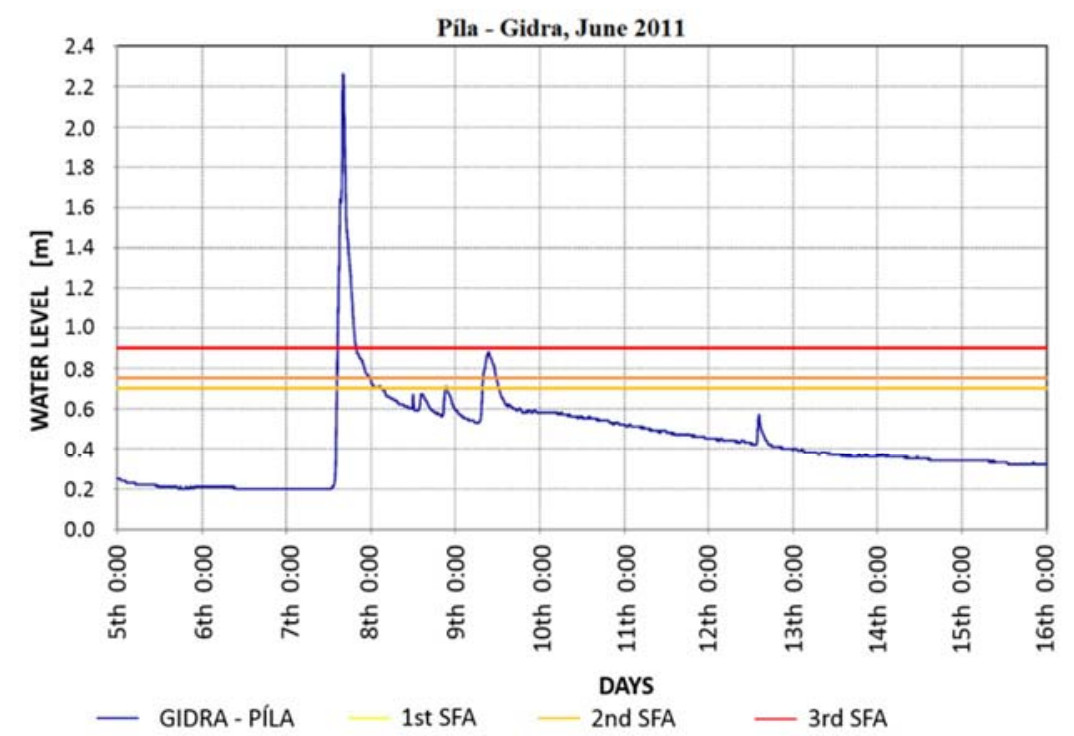

Fig. 1. Stage hydrograph of the flood in June 2011 [14]

\section{Materials and methods}

Because of availability, good experience and due to the range of gathered data, HEC-RAS program has been chosen for this modeling. Another reason was that the system is designed for application in the flood plain management and the flood insurance studies to evaluate floodway encroachments. It also includes unsteady flow components, for example as dam break analysis and dam overtopping, which were used in this study.

In general, to simulate a flood wave using the HEC-RAS program, an unsteady flow analysis has to be performed. To make this analysis, a time step needs to be chosen. This is probably one of the most important parameters entered into the model. Choosing 
this value should be done with care and consideration as to how it will affect the simulation. The computational interval should be based on several factors. First, the interval should be small enough to accurately describe the rise and fall of the hydrographs being routed. A general rule of thumb is to use a computation interval that is equal to or less than the time of the rise of the hydrograph divided by 20 . In other words, if a flood wave goes from its base to its peak in 10 hours, then the computation interval should be equal to or less than 0.5 hours (30 minutes). This way of estimating the time step tends to give an upper boundary as to what the value should be.

A second way of computing the appropriate time step is by applying a numerical accuracy criterion called the 'Courant condition'. This criterion looks at the spacing of a cross section and the velocity of a flood wave. The use of a time step based on the Courant condition will give the best numerical solution but may cause the model to run longer.

Additional considerations must be taken into account for hydraulic structures, like bridges, culverts, weirs and gated spillways. Quick changes in the elevation of a water surface can cause the solution for unsteady flow equations to become unstable. In this work a computational interval of 4-6 seconds was calculated using the Courant condition and afterwards used [15], [16]. Based on Courant-Friedrichs-Lewy condition for the one-dimensional case:

$$
C=\frac{u \cdot \Delta t}{\Delta x} \leq C_{\max }
$$

where $C$ represents the value of Courants number (dimensionless number); $u$ is the magnitude of the velocity; $\Delta t$ is the time step and $\Delta x$ is the length interval. The value of $C_{\max }$ changes with the method used to solve the discretized equation, especially depending on whether the method is explicit or implicit. If an explicit (time-marching) solver is used then typically $C_{\max }=1$.

In this case, with maximum cross-section profiles spacing $20 \mathrm{~m}$ and maximum velocity of flood water in channel $2.77 \mathrm{~m} . \mathrm{s}^{-1}$ the criterion $C$ has been 0.83 , which is less than $C_{\max }=1,[17]$.

\section{Creating a HEC-RAS model}

To create a HEC-RAS model the user has to enter geodetic and hydrological data into the program. Two types of geodetic data were available for this paper: a survey of the Gidra stream bed in the village of Píla and two valleys of the Gidra and Kamenný streams, which were surveyed by 3D scanning (Fig. 2).

The geodetic survey in Píla represented 72 profiles, including seven bridges. The geometry of the model survey was completed by the parameters of a possible third detention reservoir (Fig. 3), which could be situated approximately $1000 \mathrm{~m}$ upstream of the Gidra above the scanned valley. All the necessary data were gathered by a classical survey of the cross sections in the landscape. Accordingly, a $5.1 \mathrm{~km}$-long model of the Gidra stream with the $2.1 \mathrm{~km}$ long inflow of the Kamenný stream was created. 

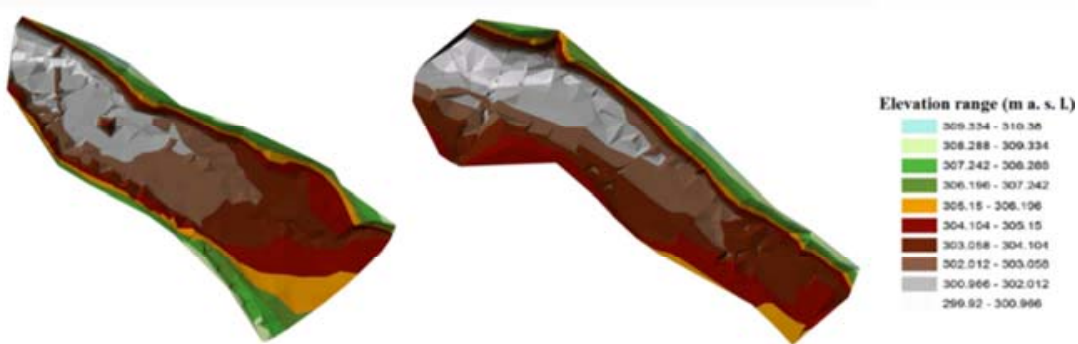

Fig. 2. Illustration of the 3D scans in the basins of the Gidra and Kamenný streams [18]

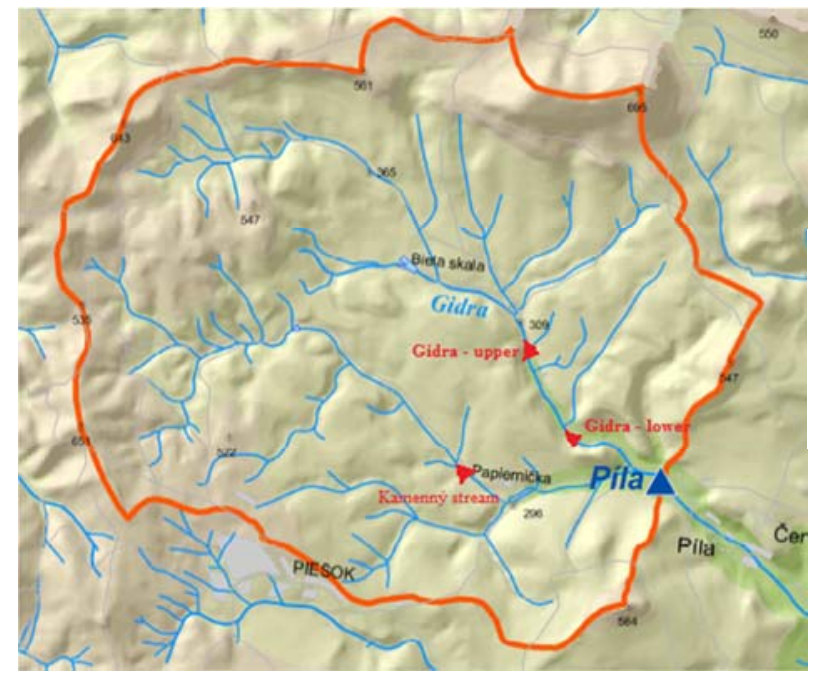

Fig. 3. Gidra river basin above the Píla village with proposed detention reservoirs

The roughness of the river basin was defined in the model by the Manning coefficient. The values from a previous thesis [19] that concerned the reconstruction of the flood on the Gidra stream in June 2011 and its impact on the levels of the groundwater was used. Specifically, the number $n=0.05$ for the channel and number $n=0.5$ was used for the floodplain. It is necessary to mention that these values are not realistic and do not correspond with the current condition of the stream. They consider circumstances like the presence of large rocks in the channel during the flood or the circumfluence of obstacles (tree branches or buildings in proximity to the flow) by the rising water level [20].

One of the possible hydrological bases of this thesis was a recording of the position of the water level during the flood on the Gidra in June 2011. It was decided not to use it for the following reasons:

- The flood on the Gidra in June 2011 was presumably affected by the breaking of blocked fences (Fig. 4), which caused a flood wave that would not have been 
shaped in the same situation without the obstacles. These fences crossed various streams and resulted in a barrier to the flow during the flood [21].

- These records of the flood wave were related to the confluence of the Gidra and Kamenný streams, so it would be problematic to divide this flood wave into two separate streams so that the progress of the water level past the confluence corresponded to the recording of the water level.

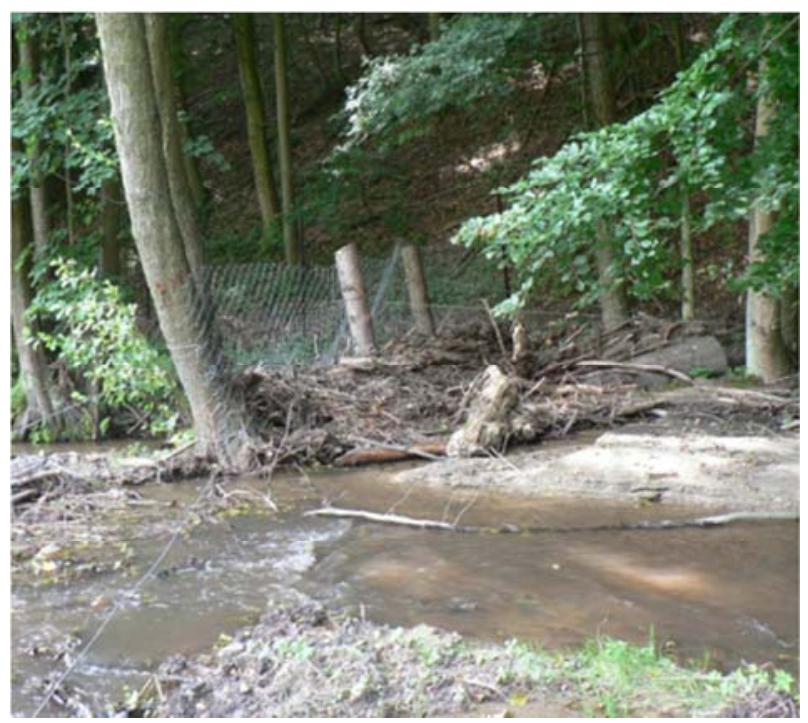

Fig. 4. A photograph of ruptured fence made shortly after the flood

Design flood waves were created based on the modeling of summer flood waves in basins without observations as a hydrological basis. The mentioned flood waves are caused by casual rainfall with a set probability of repeating (a 100 year rainfall) and a meridian discharge caused by the rainfall having the same probability of repeating. For the two identified profiles of the Gidra and Kamenný streams, sub-basins were created by a GIS-based program, where the slope and vegetation cover were analyzed. The runoff was then analyzed by adding the rainfall to the program. As a result, design flood waves with exact parameters (Table I) for the specific profiles were created in the form of a record of the discharge over time (Fig. 5).

\section{Table I}

Concrete parameters of design flood wave

\begin{tabular}{|l|c|}
\hline Time of concentration [hours] & 4 \\
\hline Design intensity of rainfall $\ln \left[\mathrm{mm} \cdot \mathrm{h}^{-1}\right]$ & 13.5 \\
\hline Runoff coefficient $[-]$ & 0.46 \\
\hline Design discharge $\left[\mathrm{m}^{3} \cdot \mathrm{s}^{-1}\right]$ & 13.74 \\
\hline Volume of design flood wave $\left[\mathrm{m}^{3}\right]$ & 400000 \\
\hline
\end{tabular}




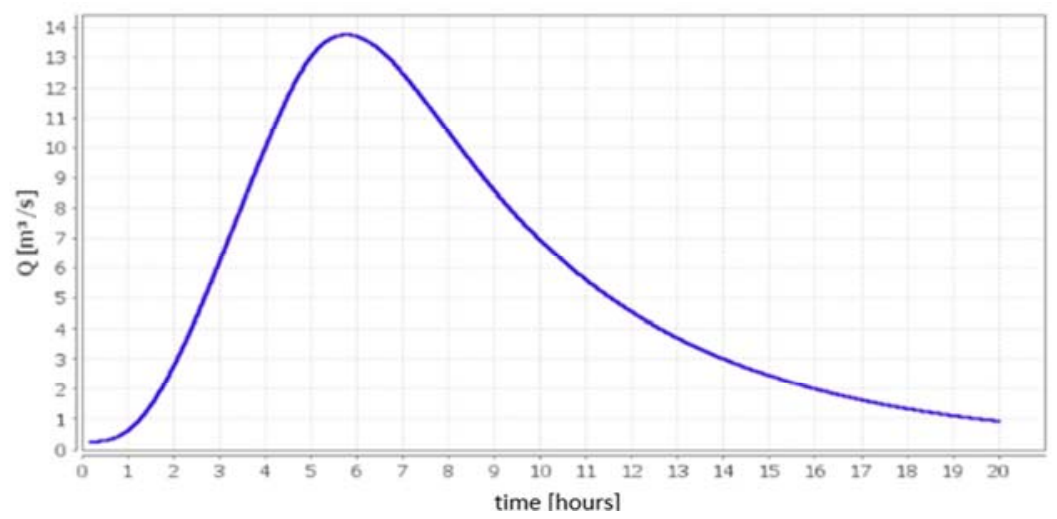

Fig. 5. Design flood wave for the profile of the detention reservoir on the Gidra stream

In the vicinity of the village of Píla various smaller tributary streams flow into the Gidra and Kamenný streams, the discharge of which is normally almost trivial (usually a few liters per second). However, during flash floods small streams can become significant inflows, which is the reason for incorporating them into the hydraulic model.

As a basis for the boundary conditions for the unsteady flow, the abovementioned flood waves have been used. The upper boundary conditions were formed as a recording of the discharge over time, and the downstream boundary conditions on the Gidra from the steady flow, which is the normal depth assigned as a longitudinal slope was used.

The model was calibrated on the basis of knowledge gained by modeling a flood reconstruction using the flood brands. Unfortunately, the flood on this stream was so rare, that there has not been any comparable flood in history of local gauging station, on basis of which this model could be verified.

After the successful simulation of the flood, the important data, which could be used as a comparison for the effect achieved by the detention reservoirs modeled, were obtained. The model was adjusted so that the flood waves on the Gidra and Kamenný streams met at their confluence at the same time, which indicates the worst possible case of flooding on these two streams. The flood wave on the Kamenný stream arrived at the junction at 6:15 p.m., and the flood wave on the Gidra arrived at 6:00 p.m. Through the synergy of those waves, which arose at the stationing of $2799 \mathrm{~m}$ (the gauging station profile), a wave with a peak discharge of $25.59 \mathrm{~m}^{3} . \mathrm{s}^{-1}$ occurred at 6:15 p.m.

\section{Evaluation of the channel's capacity}

When proposing a detention reservoir, the important value is the capacity discharge of the downstream channel and its structures. Usually, structures like bridges or culverts have less of a capacity than the channel itself, as was the case here, as well. The limited profile in view of the capacity of the channel was one of the seven bridge profiles in the village. It turned out that the most critical section of the stream was the footbridge at river kilometrage 32.006, the profile of which was almost completely clogged with 
water with a discharge of $15.3 \mathrm{~m}^{3} . \mathrm{s}^{-1}$. The bridge at river kilometrage 31.127 was also critical, and by the time of the mentioned discharge, there was only $25 \mathrm{~cm}$ of spare room under the bridge deck before the clogging.

\section{Proposed flood protection measures}

After the simulation of the flood without the proposed measures, the design of the detention reservoirs had to be made. The aim was not to propose detention reservoirs that would ensure the complete flood protection of the village. Instead, not too high reservoirs in the given locations were proposed. The reason was the fact that the natural landscape of the valleys in the Small Carpathians above the village was not to be disturbed. The current state of this area is very beautiful and natural, and would be damaged by building big dams in these valleys. Also, earth fill dams were proposed because of their more natural appearance.

There are two ways of modeling detention reservoirs in the HEC-RAS program. The user can choose to create storage areas connected to weirs or (as in this case) culverts or weirs (Fig. 6), with many cross-section profiles upstream from the construction, to ensure detailed and correct calculations of the water levels behind the structure [22].

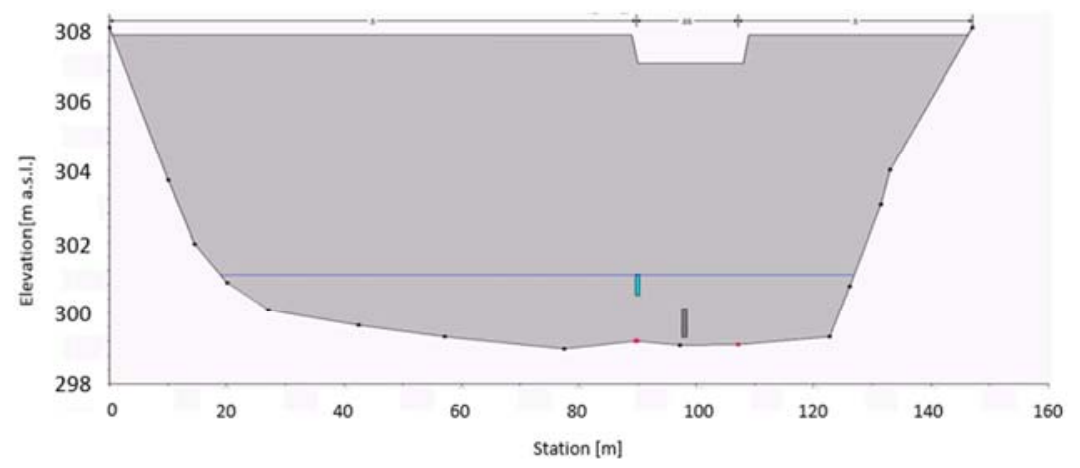

Fig. 6. Detention reservoir in the HEC-RAS program (with a blocked outlet and bypass) the rill in the crest represents an emergency spillway

These proposals are the result of many attempts and errors (the trial - error method), because it was determined that while the flood waves were passing the detention reservoirs, they would be over-spilled [23]. So, the dam crest altitudes were gradually increased by using geodetic surveying data as well as by increasing the diameter of the outlet structures. As a result, 6 proposed detention reservoir variants with exact proportions were created. The proportions from the most successful variant are:

- detention reservoir on the Kamenný stream (stationing 1840 m, river kilometrage approx. 1.84):

○ dam crest altitude - $307.8 \mathrm{~m}$ a. s. 1.;

○ dam height $-7.8 \mathrm{~m}$; 
- diameter of the outlet $-1.1 \mathrm{~m}$;

- length of the dam crest - approx. $80 \mathrm{~m}$;

- Lower detention reservoir on the Gidra (stationing 3625 m, river kilometrage approx. 34.126):

○ dam crest altitude - $289 \mathrm{~m}$ a. s. 1.;

$\circ$ dam height $-6.8 \mathrm{~m}$;

○ diameter of the outlet $-0.95 \mathrm{~m}$;

- length of the dam crest - approx. $65 \mathrm{~m}$;

- Upper detention reservoir on the Gidra (stationing $4740 \mathrm{~m}$, river kilometrage approx. 35.241):

○ dam crest altitude - $307 \mathrm{~m}$ a. s. 1.;

$\circ$ dam height $-8 \mathrm{~m}$;

- diameter of the outlet - $1 \mathrm{~m}$;

- length of the dam crest - approx. $140 \mathrm{~m}$.

\section{Results}

The result of the hydraulic modeling of the detention reservoirs above the village of Píla is the attenuating of the flood waves. A comparison of the results of a zero variant and the proposed variants with several detention reservoirs was performed. The comparison was done at a specific profile below the detention reservoirs and below the confluence of the Gidra and Kamenný streams [24].

Through the synergy of the detention reservoirs, the meridian discharge has been reduced from the original $25.59 \mathrm{~m}^{3} \cdot \mathrm{s}^{-1}$ to a value of $12.10 \mathrm{~m}^{3} \cdot \mathrm{s}^{-1}$ and has been delayed by 1.25 hours (Fig. 7).

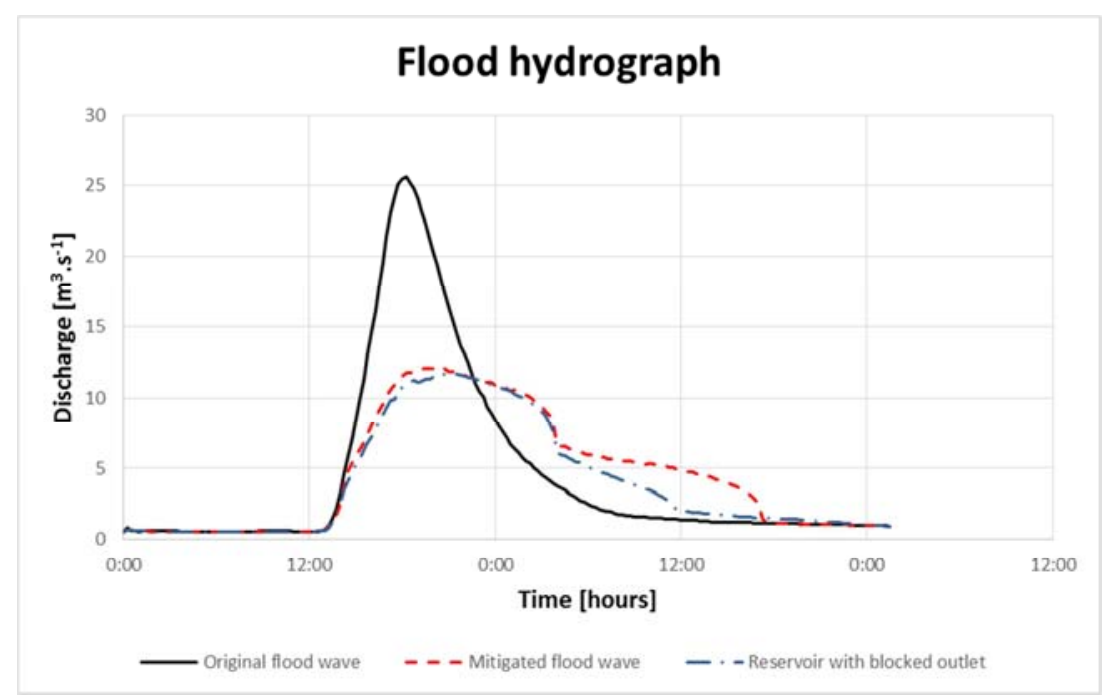

Fig. 7. Flow hydrograph - transformation of the flood wave with and without blocked outlet 
This is the result of the most successful variant - variant VI. Previous proposals were less effective, so they were gradually improved. The modeling started with only two detention reservoirs in Variant I. In Variant II the height of the detention reservoir on Kamenný stream has been increased. To create Variant III one more detention reservoir to the model from Variant I - upper detention reservoir on Gidra stream has been added. As the capacity of detention reservoirs was still insufficient, the combination of Variant II and Variant III has been formed into Variant IV. In Variant V detention reservoir on Kamenný stream from Variant II with larger upper detention reservoir on Gidra stream has been used. But only with combination of all three detention reservoirs with increased heights in Variant VI the measures were enough effective to ensure flood protection against the design flood wave. The results of all the variants are shown in Table II.

Table II

Results of all 6 variants of the proposed detention reservoirs

\begin{tabular}{|c|c|c|c|}
\hline Variant & $\begin{array}{c}\text { Original peak } \\
\text { discharge }\end{array}$ & $\begin{array}{c}\text { Reduced peak } \\
\text { discharge }\end{array}$ & $\begin{array}{c}\text { Delay of peak } \\
\text { discharge }\end{array}$ \\
\hline Variant I & & $18.19 \mathrm{~m}^{3} \cdot \mathrm{s}^{-1}$ & 1.25 hour \\
Variant II & & $16.78 \mathrm{~m}^{3} \cdot \mathrm{s}^{-1}$ & 1.75 hour \\
Variant III & $25.59 \mathrm{~m}^{3} \cdot \mathrm{s}^{-1}$ & $17.02 \mathrm{~m}^{3} \cdot \mathrm{s}^{-1}$ & 1.5 hour \\
Variant IV & & $15.68 \mathrm{~m}^{3} \cdot \mathrm{s}^{-1}$ & 2.25 hour \\
Variant V & & $14.83 \mathrm{~m}^{3} \cdot \mathrm{s}^{-1}$ & 0.25 hour \\
Variant VI & & $12.10 \mathrm{~m}^{3} \cdot \mathrm{s}^{-1}$ & 1.25 hour \\
\hline
\end{tabular}

\section{Modeling of unusual flood situations at detention reservoirs}

During the service of a detention reservoir, several circumstances may occur. One of the situations can be the blocking of the outlet during a flood. This might be caused by larger sediments (branches, twigs, etc.) carried by the stream during higher water levels in the channel (Fig. 8) [25]. The flow through the blocked outlet is significantly reduced or completely prevents water from flowing out of the reservoir. Therefore, it is necessary to propose an adequate emergency spillway. Its presence does not solve the problem completely, because the reservoir with a blocked outlet would be unable to empty. A structure called a 'bypass' is an ideal solution to this problem. It is basically another outlet that is situated above the bottom outlet. The bypass is gated and only opened if necessary (when the bottom outlet gets jammed). It should be arranged at a certain distance from the bottom outlet, and it should be possible to open and to operate it from the air side.

In order to make a simulation of this event, a flood wave passing through a detention reservoir with a blocked outlet and with a bypass was simulated. The result of this simulation is shown in Fig. 7.

There are three lines shown on this flow hydrograph. The highest one represents a flood wave in a village without any detention reservoirs; the second one represents a mitigated flood wave caused by a detention reservoir. The third one also represents a 
mitigated flood wave caused by a detention reservoir, but with a blocked outlet. The difference between the second and third lines is the volume of water that remained stored in the detention reservoir because of the blocked outlet. The most important fact demonstrated by these simulations is that the detention reservoir flattened the flood wave and worked safely due to the properly proposed emergency spillway.

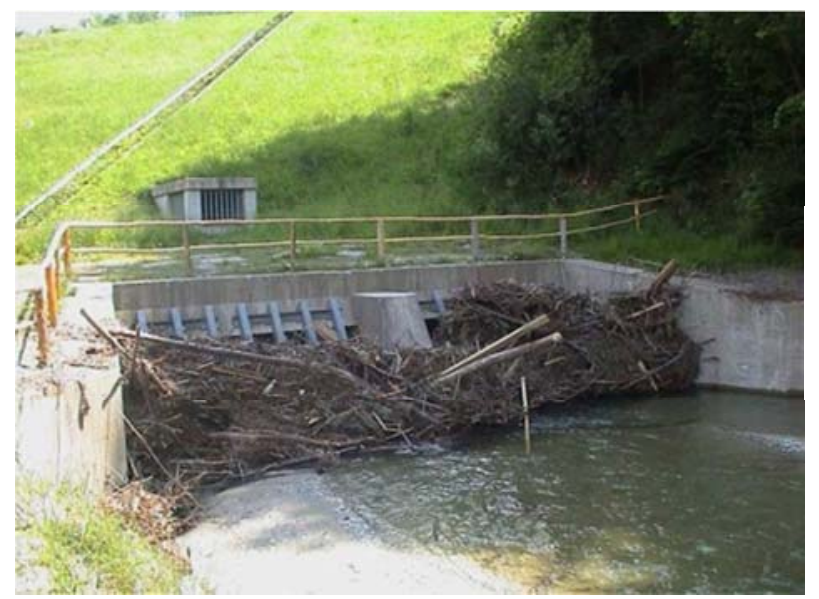

Fig. 8. Photograph of a bypass and blocked outlet at a detention reservoir [21]

Another unusual situation might be the most catastrophic one - a dam break. There is usually more than one cause of the total failure of a structure like this. In this simulated case the reasons are a flood wave with parameters higher than the design flood wave and with the return period of more than 100 years and also the defective construction of the dam itself [26], [27]. The HEC-RAS software offers two types of failure mode - overtopping or piping. Because the emergency spillway had enough capacity to withstand even larger flood wave, the failure was simulated as piping; the water started to leak through the dam and, due to suffusions and the increasing velocity of the seeping water, the dam broke [28]. If a piping failure is selected, the user must enter a piping coefficient. This coefficient is an orifice coefficient, which is used while flow is coming out of the dam in a piping mode. Typical orifice coefficients for a true designed orifice are around 0.8. However, for a piping breach, the coefficient should be lower to represent all of the additional energy losses occurring [15]. Therefore, this coefficient was chosen with a value 0.5 . Other parameters of breach plan data were: initial piping elevation, full formation time (30 minutes), breach weir coefficient and final shape of the breach. The results show how this situation affected the whole flood wave passing through the village (Fig. 9).

As it can be seen from the flow hydrograph, the failure of one of the detention reservoirs has a slightly negative effect on the passing of the flood wave - the flood is delayed but the peak of dam break flood is comparable with the peak of 'natural flood'. In this case the negative effect of the failure of the detention reservoir was partially 
reduced by a downstream detention reservoir, which could withstand the flood wave, even though the water was flowing through the emergency spillway.

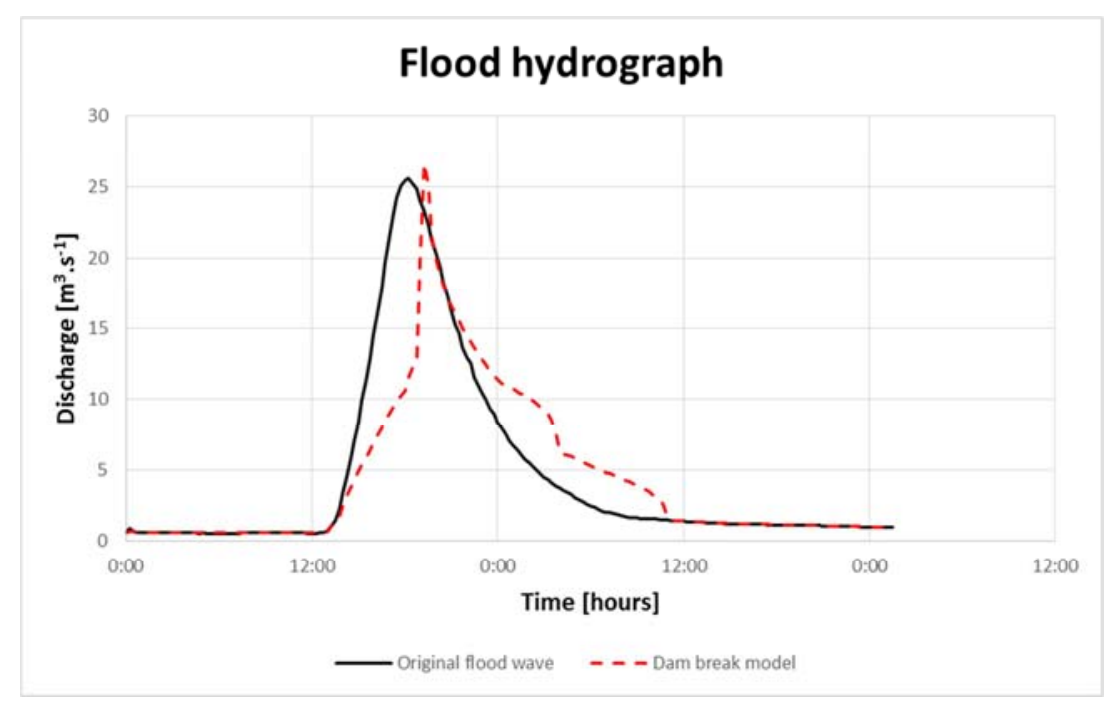

Fig. 9. Flow hydrograph - dam break model

The fact is that these dam break simulations cannot be validated, so their accuracy might not be totally correct, though they show a good example of flood water distribution during this kind of event in comparison with regular situation.

\section{Conclusion}

Through the processing of geodetic and hydrological data, the creation of a mathematical model of the Gidra stream river basin in the village of Píla and the area above the village was performed. The critical capacity discharge of the Gidra stream was determined in a bridge profile to be the value of $15.3 \mathrm{~m}^{3} . \mathrm{s}^{-1}$.

Flood protection measures with specific parameters using detention reservoirs have been proposed in the area above the village of Píla. Subsequently these reservoirs were incorporated into a hydraulic model to test the efficiency of these measures during a flood period given by a design flood wave with a likelihood of recurrence of once every 100 years. After the modeling and evaluation of the results, an accurate base for projecting the future flood protection of the village of Píla was created.

\section{Acknowledgements}

This contribution was supported by the VEGA Grant Agency under VEGA Contract No. $1 / 0800 / 17$. 
This publication is the result of the project implementation: 'Centre of Excellence of Integrated Flood protection of Territory', ITMS 26240120004, supported by the Research \& Development Operational Programme funded by the ERDF.

\section{References}

[1] Graham W. J. A procedure for estimating loss of life caused by dam failure, DSO-99-06. US, Department of Interior Bureau of Reclamation, Dam Safty Office, Denver, Colorado, 1999.

[2] Jonkman S. N., van Gelder P. H. A. J. M., Vrijling J. K. An overview of quantitative risk measures for loss of life and economic damage, Journal of Hazardous Materials, Vol. 99, No. 1, 2003, pp. 1-30.

[3] Brazdova M., Riha J. A simple model for the estimation of the number of fatalities due to floods in central Europe, Natural Hazards and Earth System Sciences, Vol. 14, No. 7, 2014, pp. 1663-1676.

[4] Simonovic S. P. Reservoir systems analysis, closing gap between theory and practice, J. Water Res. Pl-Asce., Vol. 118, No. 3, 1992, pp. 262-280.

[5] Vasan A., Simonovic S., Slobodan P. Optimization of water distribution network design using differential evolution, J. Water Res. Pl-Asce, Vol. 136, No. 2, 2010, pp. 279-287.

[6] Ayalew T. B., Krajewski W. F., Mantilla R. Exploring the effect of reservoir storage on peak discharge frequency, J. Hydrol. Eng. Vol. 18, No. 12, 2013, pp. 1697-1708.

[7] Hamel P., Daly E., Fletcher T. D. Source-control storm-water management for mitigating the impacts of urbanization on base-flow: a review, J. Hydrol. Vol. 485, 2013, pp. 201-211.

[8] Babbar-Sebens M., Barr R. C., Tedesco L. P., Anderson M. Spatial identification and optimization of upland wetlands in agricultural watersheds, Ecol. Eng. Vol. 52, 2013, pp. 130-142.

[9] Kurz B. A., Wang X., Silva L. D., Hanson S. K., Kurz M. D., Peck W. D., Simonsen T. K., Steadman E. N. An evaluation of basin-wide distributed storage in the red river basin: The Waffle concept, Energy \& Environmental Research Center, University of North Dakota, 2007.

[10] Andoh R. Y. G., Declerck C. A cost effective approach to storm-water management? Source control and distributed storage, Water Sci. Technol. Vol. 36, No. 8-9, 1997, pp. 307-311.

[11] Thomas N. W., Amado A. A., Schilling K. E., Weber L. J. Evaluating the efficacy of distributed detention structures to reduce downstream flooding under variable rainfall, antecedent soil, and structural storage conditions, Adv. Water Resour, Vol. 96, 2016, pp. 74-87.

[12] Pekárová P., Svoboda A., Miklánek P., Halmová D. Flood problems on small streams, Part I, Analysis of flood in Small Carpatheans 7 June 2011, (in Slovak) Proceedings of Conference on Risk and River Basin Managemant, Častá, Slovakia, 6-8 December 2011, Water Resarch Institute, Slovakia, 2011, http://www.vuvh.sk/download/manazmentpovodi_ rizik/zbornikprispevkov/konferencia/Prispevky/SekciaC/Pekarova_a_kol1.pdf, (last visited 10 December 2016).

[13] Slovak Hydrometeorological Institute, Flash flood on Small Carpathians streams in June 2011, (in Slovak) Flood report, Bratislava, 2011.

[14] Blaškovičová L'., Poórová J., Hazlinger M., Tausberik O., Lupták L. Flash floods in Slovakia, flash flood on Gidra and Parná in June 2011, (in Slovak) Proceedings from Conference on Risk and River Basin Managemant, Častá, Slovakia, 6-8 December 2011, Water Resarch Institute, Slovakia, 2011, http://www.vuvh.sk/download/Manazment 
Povodi_rizik/zbornikPrispevkov/Konferencia/prispevky/SekciaC/Blaskovicova_Poorova_a \%20kol.pdf, (last visited 15 December 2015).

[15] HEC-RAS Programme, Hydrologic Engineering Centre, River analysis system, US Army Corps of Engineers, 2008.

[16] Duarte M., Fonseca P., Ortigao A. Flash flood control works around the Maracana stadium district in Rio de Janeiro, Brazil, Proceedings of the Institution of Civil Engineers, Civil Engineering, Vol. 166, No. 6, 2013, pp. 44-48.

[17] Courant R., Friedrichs K., Lewy H. On the partial difference equations of mathematical physics, IBM Journal of Research and Development, Vol. 11, No. 2, 1967, pp. 215-234.

[18] Šoltész A. Small Carpathian flood protection, Presentation best project, Slovak University of Technology in Bratislava, 2014.

[19] Gloger L. Rekonstruktion des Hochwassers vom Juni 2011 und dessen Interaktion mit dem Grundwasserspiegel sudlich der Kleinen Karpaten bei Častá, Slowakei, MSC Diploma Thesis, (in Slovak) Slovak University of Technology in Bratislava, 2013.

[20] Förster S., Chatterjee Ch., Bronstert A. Hydrodynamic simulation of the operational management of a proposed flood emergency storage area at the Middle Elbe River, River Research and Applications, Vol. 24, No. 7, 2008, pp. 900-913.

[21] Pindjaková T., Kelčík S., Šoltész A. Simulation of flood progress on the Gidra river, Pollack Periodica, Vol. 11. No. 1, 2016, pp. 25-34.

[22] Kelčík S., Pindjaková T., Šoltész A. Assessment and design of the flood protection measures in the district of Levice (Slovakia), Pollack Periodica, Vol. 11. No. 1, 2016, pp. 35-41.

[23] Yazdi J., Salehi Neyshabouri S. A. A. Optimal design of flood-control multi-reservoir system on a watershed scale, Natural Hazards, Vol. 63, No. 2, 2012, pp. 629-646.

[24] Madadi M. R., Azamathulla H. M., Yakhkeshi M. Application of Google earth to investigate the change of flood inundation area due to flood detention dam, Earth Science Informatics, Vol. 8, No. 3, 2015, pp. 627-638.

[25] Jobst C., Hammer A., Hornich R., Zenz G. Retention basins, experience of flood control in Styria, Proceedings from conference on ${ }^{\text {th }}$ ICOLD Europien Club Symposium, Innsbruck, Austria, 22-23 September 2010, https://online.tugraz.at/tug_online/voe_main2. getvolltext?pCurrPk=52911, (last visited 10 December 2016).

[26] Liang Q., Borthwick A. G. L., Stelling G. Simulation of dam- and dyke-break hydrodynamics on dynamically adaptive quad-tree grids, International Journal for Numerical Methods in Fluids, Vol. 46, No. 2, 2004, pp. 127-162.

[27] Alhasan Z., Jandora J., Riha J. Study of dam-break due to overtopping of four small dams in the Czech Republic, Acta Universitatis Agriculturae et Silviculturae Mendekianae Brunensis, Vol. 63, No. 3, 2015, pp. 717-729.

[28] Lee B. S., You G. J. Y. An assessment of long-term overtopping risk and optimal termination time of dam under climate change, Journal of Environmental Management, Vol. 121, 2013, pp. 57-71. 